\title{
NIGERIA'S 2007 GENERAL ELECTIONS AND THE SUCCESSION CRISIS Implications for the Nascent Democracy
}

\section{Emmanuel O Ojo}

\author{
Dr Ojo is a Senior Lecturer in the Department of Political Science \\ at the University Ilorin, Nigeria \\ PMB 1515, Ilorin, Kwara State, Nigeria \\ Tel: + $022008330(\mathrm{~h}) ;+08033822383$ (cell) \\ e-mail: eojo12000@yahoo.com
}

\begin{abstract}
Undoubtedly, the events of the 2007 general elections coupled with the verdict of both local and international observers clearly demonstrated that the entire electoral process was controversial, thereby making the election flawed. The concomitant effect is a crisis of political succession, which has always been the bane of Nigeria's march to democracy. Thus, the thrust of this paper is an in depth analysis of the elections vis-à-vis political succession. After an introductory overview the paper proceeds to a conceptualisation of political succession, which forms its theoretical framework. Part three dwells on the flawed elections, discussing what went wrong. The final section calls for the restructuring of Nigeria's electoral system and recommends a number of remedies. The paper, however, infers that without a credible election sustainable democracy in Nigeria may become a mirage after all.
\end{abstract}

\section{INTRODUCTION}

Nigeria has had more than its fair share of transitions: from authoritarian colonial rule to elected democratic rule; from elected democratic rule to elected undemocratic regime (for instance from 1962 with the First Republic and from 1982 with the Second Republic, when elected civilians began to treat the democratic order with disdain, especially as it relates to the sanctity of the electoral process and of fundamental freedoms and group rights); from civilian to military rule and vice versa; and from one military regime to the other (Ojo 2004, pp 6382). Despite all these changes the country has yet to witness a successful, orderly 
and constitutional transfer of power from one democratic regime to another (Oyediran \& Agbaje 1999, p 14). Simply put, the political albatross is that of peaceful, genuine political succession from civilian regime to civilian regime (Ojo 2006a, 254-272).

In a nationwide survey the International Institute for Democracy and Electoral Assistance (International IDEA) identified a number of factors responsible for the chaotic political succession in Nigeria. They are:

- lack of discipline in the form, spirit and implementation of the election process;

- excessive monetisation of politics in general;

- a 'winner-takes-all' philosophy pervasive among the political elite;

- the general level of poverty and illiteracy;

- the absence of clear ideological underpinning of the parties; and

- religious bigotry and, to a limited extent (now a large extent), ethnic chauvinism

International IDEA 2001, p 218

Nigeria's experience vis-à-vis political succession lends credibility to the findings of the survey. In the 39 years from independence in 1960 to the democratic transition of 1999 civilians have ruled for a little more than nine years, while the military was in power for a total of just over 29 years. The immediate post-colonial civilian government under Balewa lasted for just more than five and was followed by the first period of military rule spanning the period 15 January 1966 to 30 September 1979. The civilian interregnum of the Shagari era was short lived, lasting from 1 October 1979 to 31 December 1983; it ended with the return to power by the military, whose second period of rule - more entrenched and pervasive - lasted from 1 January1984 to 28 May 1999. To date Nigeria has experienced five successful military coups or / and counter coups (in January 1966, July 1966, July 1975, December 1983, and August 1985), three inter-military arranged 'palace' transfers of power (in August and November 1993 and June 1998), and at least two major abortive countercoup attempts (in February 1976 and April 1990) (Adekanye 2005, pp 9 \& 10). All of this indicates chaotic political succession.

\section{POLITICAL SUCCESSION}

Political succession means the transfer of political power from one group to another. The degree of orderliness with which the transfer is carried out is viewed as evidence of maturity on the part of the state and is an internationally accepted 
barometer for assessing both the consolidation and the quality of democracy in a polity at any particular point (Diamond \& Morlino 2004, pp 20-31; also see Schumitter 2004, pp 47-60). As Kris Obodumu (1992, pp 237-56) correctly observed, a discussion of political succession in Africa 'has the tendency to instantly direct academic imagination to the backward phenomenon of violent and unconstitutional overthrow of governments'.

Be that as it may, succession is classified into orderly or regular and disorderly or irregular. For Blondel (1980) regular succession of national political leadership involves adherence to some kind of rules or procedures of transfer, or should at least accord with the spirit of existing procedures. Conversely, irregular succession would involve a failure to adhere to procedures or a crisis in the process of transfer, a phenomenon Blondel (1980) sees as being on the increase in sub-Saharan Africa and which, to him, often takes the form of military coups in the region.

The problem is that Blondel's analysis is founded on a Western bourgeois perception of political succession which takes little account of the existential realities of the African context, which is quite antithetical to Western ideals of democracy. In the words of Larry Diamond and Leonardo Morlino (2004) 'talk of a "good" or "better" democracy implies knowing what democracy is'. At a minimum, democracy requires universal, adult suffrage; recurring, free, competitive and fair elections; more than one serious political party; and alternative sources of information (Dahl 1971).

If elections are to be truly meaningful, free, and fair, there must be some degree of civil and political freedom beyond the electoral arena so that citizens can articulate and organise on the basis of their political beliefs and interests. Once a country meets these basic standards, further empirical analysis can ask how well it achieves the three main goals of an ideal democracy - political and civil freedom, popular sovereignty (control over public policies and the officials who make them), and political equality (in these rights and powers) as well as broader standards of good governance (such as transparency, legality, and responsible rule) (Diamond \& Morlino 2004). It is imperative to state that rarely in Africa has any vote beyond the first vote at independence determined political outcomes (Londregan, Biernen \& Van de Walle 1995, pp 1-25). This has been the root cause of succession crises across the continent and particularly in Nigeria.

Nevertheless, leadership succession and regime change lie at the centre of two perennial problems of governance: how to ensure the political continuity of any regime without endangering the stability of the political community and how to protect both the regime and the political community against the natural disposition of those in power to attempt to extend their term of office or succeed themselves against the provisions of written or unwritten rules of managing political power and succession rights. 
There can be little doubt, then, that the political acts that surround leadership succession and regime change constitute a serious aspect of political life in any society. In political systems in general, and in African politics in particular, such acts constitute an important index of development or determination of politics (Anise 1974, pp 507-24). It should be recognised that there are aspects of both regime change and leadership succession that make it possible to study them at several sub-national levels. For example, we can study succession at the city (mayoral) level, country level, state level (succession of congressional representatives or governors), or at the national level (national congressional succession, Supreme Court succession and presidential succession), which is the focus of this study. In a nutshell, leadership succession exists, for example, whenever the head of the government is replaced by another person (Anise 1974). In the same vein, there is leadership succession when there is a transfer of power from one party to another but without major policy or ideological changes. In his typology of leadership succession Ladun Anise (1974) classified (a) conditional and (b) unconditional procedures of leadership succession. He went further to state that, in the African context, there are five types of leadership succession: assassination, coup d'état, abdication and/or resignation, and constitutional procedures. It is important to note that any of these modes, or a combination, could result in a succession crisis.

In the literature on political succession generally scholars have tried to ascertain whether there are basic features or even patterns that allow for a reasonable prognosis of failure. There have been many attempts to build models and develop new approaches to cast some light on the politics of succession in communist systems in general (Sandschneider 1985, pp 638-58). It is instructive to note that analysts of Soviet politics have put forward at least three different models:

- A totalitarian model, which regards the individual leader's personal and all-encompassing rule as 'paramount in determining the nature of both public policy and political structures'.

- A conflict model, which 'suggests that policy and political structures are shaped by the nature of the conflict between individuals jockeying for political power'.

- A bureaucratic model, which places less emphasis upon the individual leaders, suggesting that the way in which a system is governed is more a function of rules and norms within the political system. 
In the specific context of Chinese politics Robinson suggests four approaches:

- An environmental approach focusing 'on such matters as the stage and direction of the Chinese economy, the population-food balance, the Soviet border threat, and the status of Taiwan, rather than on how political decisions themselves are made'.

- A personality approach, particularly discussing 'individuals, personalities, factors, and the generational question'.

- A societal approach, which postulates that society (defined as the social environment, including 'the set of influences that stem from Chinese culture, Chinese history, and the structure and operation of Chinese social-political familiar-economic institutions') determines politics.

- A political approach, which regards politics as 'an atmosphere in which all political actors are immersed and which immutably conditions their every act'.

Cited in Sandschneider 1985

Pye (1976) differentiates between three perspectives on the succession question in China. These are:

- an historical perspective;

- a psychological perspective focusing on the dominant role of Mao;

- a generational perspective, which arises from the structures of clearly defined revolutionary generations within the Chinese leadership elite.

However elaborate and sophisticated the approaches described above may be they are unsatisfactory because crucial elements of political succession in communist systems remain unknown to us. It may not serve any useful purpose to extend the typology and conceptualisation further in view of a lack of consensus among scholars about what order political succession should take. But for the purposes of this paper an orderly transfer of power from one political elite to another via the ballot box reflects our understanding and perception of the concept. We now proceed to a brief survey of the political succession crisis in Nigeria to date.

\section{NIGERIA'S SUCCESSION CRISIS}

Nigeria's succession crisis dates back to 15 January 1966 when the first military coup was staged in which the Prime Minister, Sir Abubakar Tafawa Belewa, was killed and General Aguiyi Ironsi, the most senior military officer, took over the 
mantle of leadership. Ironsi's government suffered enormously from a legitimacy crisis (Ojo 2003a, pp 104-30). The greatest policy mistake he was accused of making was the 24 May 1966 Decree 34 he promulgated, which unified the country's civil service, thereby changing from a federal to a unitary system. The concomitant effect of this policy somersault is a perceived sense of domination by a section of the country (the Northerners). This fear is understandable taking adequate cognisance of Nigeria's ethnic mix as a plural and deeply divided society. The policy blunder eventually ignited the coup that terminated Gen Ironsi's life.

Nigerians believed the military had an established hierarchy and would stick to the tradition of seniority in the force, allowing the most senior officer, Brigadier Babafemi Ogundipe, to take over. But this was not to be. Those who killed Ironsi selected General Yakubu Gowon, who was junior to Ogundipe, as head of state. The latter's leadership was repudiated by the northern oligarchy because he was a Yoruba man. General Gowon's leadership was also resented by Col Ojukwu, an Igbo officer and military governor of the defunct Eastern Region. In view of the fact that the northern officer was considered far too junior, officers from both the east and the west lost a sense of belonging in the federation.

This succession crisis led to an agonising civil war from 1966-1970. After a nine-year reign Brigadier-General Murtala Muhammed, capitalising on the general disdain for the government occasioned by the needless postponement of the handover from the military to the civilians coupled with the unprecedented kleptocracy that characterised Gen Gowon's regime, toppled his government in July 1975. Mohammed's regime was, however, short lived - reactionary forces represented by Col Dimka's abortive coup assassinated him, thereby allowing Gen Olusegun Obasanjo to assume the mantle of leadership in February 1976. In 1979 he handed over to civilian rule.

After 13 years of continuous military rule the civil populace became weary of military governments and anxiously awaited a civil regime, which, they assumed, would end the crises of legitimacy and succession. However, the election conducted by Gen Obasanjo's administration, which ushered in the Second Republic, was widely perceived to have been rigged by the military in favour of Alhaji Sheu Shagari. This resulted in a protracted legal battle between the Unity Party of Nigeria (UPN) and the National Party of Nigeria (NPN) - now both defunct.

The outcome of the litigation in favour of the ruling party, the NPN, resulted in a loss of faith in the Federal Electoral Commission (FEDECO), in the police, the executive, the legislature and the judiciary. The gap between government and governed widened, compounding the crisis (Ojo 2003a), and it was during that crisis that Generals Buhari and Idiagbon and their cohorts emerged at the helm in 1983. Their government lasted until 1985 when Gen Ibrahim Badamosi 
Babangida terminated it in a palace coup, promising that his would be the last military government. Ironically, it was he who annulled the election of 12 June 1993. The attendant political logjam occasioned by his cutting short the longdrawn-out transition programme forced him to step aside and hurriedly put in place an Interim National Government (ING) headed by Chief Earnest Shonekan (Ojo 2004).

The interim government was declared illegal by a High Court in Lagos and on 17 November 1993 Gen Sani Abacha staged a coup, dissolving all the democratic structures sustained by the ING, and the country once again reverted to a full-blown military dictatorship. Abacha's administration was notorious for horrendous human rights violations, unprecedented kleptocracy, hostage taking, forced exile and the physical elimination of opponents (Adesina 1998, p 63). Abacha died on 8 June 1998 in mysterious circumstances.

Gen Abdulsalam Abubakar, who took over after Abacha's death, appeared to have learned a lesson from the legitimacy and succession crises of his predecessor and his transition programme was short. By 29 May 1999 he had handed over to Chief Olusegun Obasanjo.

The journey to the electoral sham of 2007 began with Abubakar's transition programme, which was not sufficiently entrenched to bring into being a democratic government - an administration that is inherently illegitimate cannot be a catalyst for democracy. By the time Obasanjo had settled the style of his governance glaringly reflected his military background and turned out to be a liability rather than a blessing for democracy. The 2003 general elections, which were handled by his administration, were perceived to have been rigged. Okechukwu Ibeanu (2007, pp 49-63), in a perceptive work on that election, noted that 'we can directly or indirectly include the more than 600000 votes cast in the presidential election over those cast in the gubernatorial election in Ogun State'. ${ }^{1}$ Two million votes were won by the PDP gubernatorial candidate in Rivers State, a victory the PDP Chairman ironically described as historic.

Although the widespread perception that the elections were rigged was a cause for worry Nigerians were unanimous in their determination to put their misgiving aside and to move on, in the hope of sorting out their election problems the next time. That 'next time' was the 2007 elections (Adetula, Albert \& Marco 2007, pp 233-47). It is paradoxical, however, that many of the problems associated

1 Figures published on the INEC website show that in the presidential ballot in Ogun State more than 600000 votes were cast over and above the total for the gubernatorial poll which was held simultaneously. This suggests that more than 600000 voters voted for the presidential candidates and took the gubernatorial ballot papers away with them - a preposterous suggestion with no evidence to support it. 
with the 2003 elections were replicated with even greater intensity in 2007 and that is the main thrust of this paper, which now turns to the conduct of the 2007 general elections and another succession crisis.

\section{THE 2007 ELECTIONS: WHAT WENT WRONG?}

The 2007 elections were remarkable in a number of ways. First, they followed eight tumultuous years of democracy - the longest period since independence from the United Kingdom in 1960 (The Nation 3 August, p 8). Secondly, for the first time in the history of the country there was a civilian-civilian transfer of power. It would have been even more remarkable if there had been a transfer of power from the ruling party to the opposition. The election was kick-started on 14 April with gubernatorial and state houses of assembly elections. A week later, on 21 April, the presidential and National Assembly elections took place across the country, with a total of 50 registered political parties jostling for office and fielding candidates at different levels. However, only 25 of the 50 actually contested the presidential polls.

Of the parties which participated in gubernatorial contests in the 36 states of the federation, the ANPP won in two states - Borno and Yobe - while the AC won in Lagos State and the PPA in Abia State. The remaining states went to the ruling party in a fiercely contested 'landslide' victory, to the consternation of the opposition parties.

The election was generally perceived to be the worst in the history of election administration in Nigeria, with both local and international observers concluding that it was badly flawed. The beneficiary of the elections, Alhaji Umaru Yar' Adua, admitted that the nation's electoral process lacked credibility and that the 2007 elections fell short of international standards. In his words: 'The April elections were so heavily marred by vote rigging that European Union observers said they fell far below basic international standards and were not credible' (Nigerian Tribune 29 August, p 1).

This general opinion, as President Yar'Adua admitted, compelled the new administration to inaugurate a 22-man electoral reform committee. ${ }^{2}$ The fundamental question at this juncture is: What really went wrong with the elections?

2 The members of the committee, which was inaugurated on 29 August and has a year to complete its assignment, are: Mohammadu Lawal Uwais, chairman and former chief justice, Godwin U Ononiba, Olisa Agbakoba, Okon Uya, Ahmadu Kurfi, Musiliu Smith, Bolaji Akinyemi, Gambo Balarabe Abdullahi, Grace Alele-Williams, Toyin Olakunmi, Jibrial Ibrahim, Oladayo Popoola, Ahmed Lemu, Attahiru Jega, Ndamusa Alao, John E Odah, Abduahim Ujo, Dije Bala, Aliyu Umar, Steven Dike, Festus Okoye, Hassan Kukar. For information on the background of each member see The National, Lagos, 23 August 2007, pp 1\&2. 


\section{Election Administration}

The 2006 Electoral Act charges the Independent National Electoral Commission (INEC) with sole responsibility for conducting elections. The 2007 elections, however, revealed serious logistical problems long before election day.

The problems began with the compilation of the voters' register. INEC opted for an electronic system, using imported direct data-capture machines. The system generated heated debate and Prof Maurice Iwu, INEC chairman, was called before the National Assembly on two occasions to convince them that there would be no hitches. In fact, the machines were grossly inefficient and required electricity to charge the batteries (this in a country which is experiencing incessant power cuts, with some communities being in total darkness for long periods) and the system left many Nigerians disenfranchised.

Once the chaotic registration process was over the registers were not effectively displayed and on election day many voters could not identify where exactly they should vote, particularly since polling booths were not clearly marked. ${ }^{3}$

According to both local and international observers, there was a lack of secrecy in the voting process, with voters who required help to vote doing so observed by security agents, party agents and other voters. The process was inefficient, with voters waiting for hours to confirm whether their names were on the voters' register and many being turned away because their names did not appear.

The performance of many of the ad hoc officials recruited by INEC was lacklustre, with agents arriving late at polling stations, some coming only a few hours before polling was due to close (Tell 7 May, pp 16-29). ${ }^{4}$ In the same vein, there were insufficient supplies of some vital electoral materials, particularly results forms. Party agents who were visible at polling centres were helpless because forms were not available to enable them to compare INEC's results with those from their agents in the field.

Security arrangements were inadequate despite the fact that the movement of citizens was restricted throughout the election period and policemen, along with other state security and law enforcement personnel, were deployed to man polling booths. Soldiers were drafted to major cities to complement the police, but they were not permitted to make arrests. The result was that ballot papers

3 This writer was an observer; the above account is based on incidents he witnessed.

4 Governor Orji Uzor Kalu of Abia State, who voted at about 7 pm, said the late arrival of election materials in his home state was a ploy to cheat him and the entire Igbo race (Sunday Tribune, Ibadan, 22 April 2007, p 5). 
and boxes were snatched and burnt and voting was disrupted in several centres. In some areas a number of policemen were arrested by soldiers for openly thumbprinting ballot papers in booklets in favour of the ruling party, while opposition party agents and other supporters were intimidated by political thugs (The News 29(8) 3 September).

Insufficient time was set aside before the election to train electoral officials and neither regular nor ad hoc staff was well enough trained to man elections successfully in a country of Nigeria's size and diversity. To compound the problem many electoral officials compromised themselves, thereby doing enormous damage to the credibility of the elections.

INEC was far from being independent and was unable to assert its autonomy and to treat candidates impartially. For instance, despite the provisions of the 2006 Electoral Act, INEC ignored Vice-President Atiku Abubakar until a ruling of the Supreme Court, only four days before the presidential election, declared him eligible to stand. This introduced a new and perhaps the most difficult challenge to the provision of ballot papers, which had already been printed. The commission was forced to print 65-million new papers in three days. 'As gathered, these new ballot papers arrived the country at $10.00 \mathrm{pm}$ on the day before the presidential election and the commission had the Herculean task of distributing the ballot papers all over the country' (People July, pp 16-24).

Perhaps what actually brought INEC to its knees was the allegations of the active connivance of INEC officials in rigging the vote. The number of aggrieved politicians who have taken their problems to election petition tribunals is unprecedented (The Nation 26 August, pp 16 \& 47). The orgy of violence which tainted the elections and gripped the polity both during and after them was also unprecedented. During the gubernatorial and state house of assembly elections the police recorded a total of 265 cases of electoral offences and violence and 1093 people were arrested. Eleven civilians and 39 policemen died in the violence. ${ }^{5}$ (See Table 1 below for a state-by-state breakdown.)

Election violence became frightening when an oil tanker with no one in it was found stationed close to the INEC headquarters, a heavy stone placed on the accelerator. The INEC chairman blamed the failed bombing bid on 'desperate Nigerians not interested in contesting the elections' ${ }^{6}$ In another incident a bizarre and brazen attempt was made on the life of a state electoral commissioner. In a detailed report, the lead story of ThisDay, Abia State Resident Electoral Commissioner Prince Solomon Soyibe wrote a petition to the Inspector General

5 For a breakdown of cases report across the country during these elections, see ThisDay 10 May 2007.

6 For a graphic account of the planned attack on INEC national headquarters see all national dailies 22 April 2007. 
Table 1

Statistics of Cases Recorded by Police During the Gubernatorial and State House of Assembly Elections

\begin{tabular}{|c|c|c|c|}
\hline Command & Cases & Suspects & Person(s) killed \\
\hline Abia & 10 & 33 & - \\
\hline Adamawa & 3 & 18 & 8 \\
\hline Akwa Ibom & 6 & 52 & - \\
\hline Anambra & 6 & 27 & - \\
\hline Bauchi & 12 & 30 & - \\
\hline Bayelsa & - & - & - \\
\hline Benue & 5 & 24 & - \\
\hline Borno & 10 & 25 & - \\
\hline Cross River & 4 & 14 & - \\
\hline Delta & 4 & 8 & 1 \\
\hline Ebonyi & 10 & 56 & - \\
\hline Edo & 10 & 24 & 5 \\
\hline Ekiti & 4 & 19 & - \\
\hline Enugu & 6 & 19 & - \\
\hline FCT Abuja & 4 & 4 & - \\
\hline Gombe & 15 & 88 & - \\
\hline Imo & - & - & - \\
\hline Jigawa & 2 & 11 & - \\
\hline Kaduna & 10 & 25 & - \\
\hline Kano & 11 & 24 & 16 \\
\hline Katsina & 11 & 76 & - \\
\hline Kebbi & 6 & 6 & - \\
\hline Kogi & 9 & 57 & 2 \\
\hline Kwara & 4 & 10 & - \\
\hline Lagos & 10 & 23 & 9 \\
\hline Nasarawa & 7 & 40 & - \\
\hline
\end{tabular}




\begin{tabular}{|lc|c|c|}
\hline Niger & - & - & - \\
\hline Ogun & 11 & 21 & 1 \\
\hline Ondo & 14 & 73 & - \\
\hline Osun & 11 & 67 & 1 \\
\hline Oyo & 13 & 83 & - \\
\hline Plateau & 2 & 9 & - \\
\hline Rivers & - & - & - \\
\hline Sokoto & 20 & 13 & $\mathbf{5 0}$ \\
\hline Taraba & 5 & 15 & - \\
\hline Yobe & 2 & $\mathbf{1 0 8 3}$ & \\
\hline Zamfara & 3 & & \\
\hline Total & $\mathbf{2 6 0}$ & & \\
\hline
\end{tabular}

Source: INEC, Abuja and ThisDay 10 May 2007

\begin{tabular}{|lr|}
\hline Summary \\
\hline Total number of cases reported & 260 \\
\hline Total number of people arrested & 1083 \\
\hline Total number of civilians killed & 11 \\
\hline Total number of policemen killed & 39 \\
\hline
\end{tabular}

of Police alerting him to a plot to eliminate him (Soyibe). In the petition, routed through the Abia State Police Commissioner, Soyibe alleged that the chairman of the PDP in the state had attempted to throw him out of an aircraft when he came to Abuja to attend an INEC meeting. Soyibe claimed that he was saved by alert security officials at the Nnamdi Azikiwe International Airport when he was attacked by hoodlums who asked him 'why he did not declare PDP the winner of the governorship election in the State'. Soyibe claimed that if he had not held on to the railings of the aircraft steps he would have been pushed down to die.

Summarising the flaws in the 2007 elections a report in the New York Times (cited in The Nation, Lagos, 23 April 2007, p7) described the late arrival of ballot papers at most polling stations and the fact that the presidential ballots were printed without vital information to identify candidates and prevent fraud. In some cases voting for legislative seats was postponed because of an absence of 
ballots, in others, voting started late and progressed slowly. There were widespread reports of shortages of presidential ballots in several states and, despite the fact that few people had been seen to vote, turnouts were recorded on tally sheets as being as high as 100 per cent in some areas, with the vast majority of votes going to the governing party.

In an editorial The Nation expressed the view that in most states the election was marred by stuffing of ballot boxes, the alternation and inflation of figures, the absence of requisite voter materials and the deployment of force and intimidation to cow opposition party representatives. In some instances the overt use of firearms crippled legitimate counting and the collation of results, with a deputy governor debasing his office by being at the forefront of this shameful episode. As The Nation noted in an editorial (19 April, p 16) in more than a dozen states there could be no joy over the conduct of the elections. 'Apart from Ondo, Edo and Osun states, other such states include Delta, Ekiti, Oyo, Independent National Electoral Commission (INEC) under Prof. Maurice Iwu has tagged itself as a partial and compromised umpire while President Olusegun Obasanjo has exposed his credentials as a democrat to the counterfeit and pitiful.' In essence, elections were far from being free and fair in most states, as observed in the editorial comment.

At the ongoing election petition tribunal sitting in Oyo State the Forum of Oyo State Governorship Candidates protested against malpractices perpetrated by the PDP.

In the whole of Oyo North and parts of Oyo central and South Senatorial districts, the logo, party name and photograph of the DPA gubernatorial candidate was, according to them, omitted from the ballot paper and the logo of the DPN was incorrect, thereby disenfranchising the candidates and the electorate.

The News 3 September, p 23

In their words, the election was:

[m]arred by wide spread electoral malpractices, monumental irregularities and violation of electoral processes in favour of the PDP, especially in Lagelu, Ogbomosho North, Ogbomosho South, Orire, Ogo-Oluwa, Surulere and Iseyin local government areas.

In their submissions they lamented that confidence in the participants who had participated in the gubernatorial and House of Assembly elections had been eroded by the results declared by INEC. They maintained that in those areas elections were: 
[c]haracterized by violence, sporadic shooting, seizure of several ballot boxes containing votes already cast and taken to unknown destinations by thugs in connivance with agents of PDP and, in some cases policemen and INEC staff.

The News 3 September, pp 24-9

It is not surprising, therefore, that civil society organisations, local and international observers, and foreign journalists who monitored and covered the elections concurred that it was the worst in the annals of elections in Nigeria (The Guardian 24 April 2007, pp 10 \& 11 and Tell 7 May 2007, pp 24-9).

There is no doubt that any government which emerges from such a sham election can only suffer from a legitimacy crisis. It is against this background that the newly inaugurated president, Umar Yar'Adua, is pursing electoral reforms to 'anchor our democratic culture firmly with everlasting peace, security and political stability'. He avers, further, that 'this would enable us to turn our collective energy and effort to developing our nation from its current state of under-developments to join the league of developed nations' (Nigerian Tribune 29 August, p 4).

\section{DIMENSIONS OF ELECTORAL REFORM}

There is no doubt that the electoral system is in dire need of reform, but if such reform is not to be a mere cosmetic exercise it must be profound and touch on virtually all aspects of election administration. To begin with, INEC must be independent and be seen to be independent, not merely in name but structurally, legally, and financially. To attain this it must be detached from the apron strings of the executive arm of government. Appointment of the commission's chairman and state resident electoral commissions should not be the exclusive preserve of the president, because he who pays the piper will definitely dictate the tune.

Similarly, key INEC personnel should have security of tenure once appointed, as does the chief justice of the federation. INEC's financial autonomy is of paramount importance - the commission should be provided with a fund on which it can draw without executive interference. Such changes will entail constitutional amendments.

The commission should be relieved of a number of functions, particularly the security and financial screening of candidates, functions other state institutions can undertake.

Another stakeholder that cannot be ignored in the reform process is political parties, which are critical to the consolidation of democracy in any polity. The major change necessary in this area is to ensure that they are a catalyst to 
democratic sustenance. To perform this function they should be a training ground for democrats. This process begins with the conduct of primary elections. At critical moments before the last election most parties failed in the conduct of primary elections, causing disharmony among their members and unnecessarily heating up the polity. In terms of the mobilisation and sensitisation of the citizenry prior the election the parties could not live up to expectations.

Campaigns should be enlightened and issue-based instead of being used to impugn other parties and their representatives. Interestingly, not many Nigerians can immediately identify the symbols of the 50 political parties, let alone describe their manifestoes or ideology. It is imperative that parties educate their members.

The judicial system must be altered to allow for speedy trials for electoral offences and hearings of grievances immediately after an election and before the inauguration of a new government. A system in which an interloper can hold sway for a lengthy period before justice is done is inadequate.

The saga of Amambra State, where Dr Chris Ngige of the PDP had ruled for more than two years before he was declared a usurper, is still fresh in our memory. If justice delayed is justice denied the system should allow for the lapse of a reasonable amount of time between election and inauguration.

Another important area is security arrangements for elections. Security agents must be properly trained in the roles they are expected to perform both during and after an election. The current tendency to over protect the ruling party is unacceptable. Security agents must be seen to be impartial and must resist being used for election rigging.

The Nigerian state itself must be strong enough to discharge its duties effectively. Currently, the state is weak and dominated by individuals who are too powerful to be brought to book in cases of electoral misdemeanours. ${ }^{7}$ In the recent past a number of politicians have assumed the status of 'godfather' to contestants, commanding thugs, hoodlums and militias who terrorised, injured and annihilated their perceived enemies or opposition. As far as the police were concerned, these 'godfathers' were 'untouchables' and their homes 'embassies'

7 Shortly after the general elections the outgoing governor of Oyo State attempted to conduct local government elections before handing over to his successor from the same party (the PDP). This did not, however, go down well with some party stalwarts. Their reaction was to mobilise thugs who fought their way to the premises of the state broadcasting corporation, attacking and injuring a number of journalists, including a TV newscaster, who was broadcasting at the time. The studios were vandalised. To date, no arrests have been made because the brain behind the attack was too strong a personality to be arrested. Both radio and television stations of the corporation went off air for days until a new governor was inaugurated who reopened it. The incident was widely reported in all the national dailies. 
the police could not enter to effect arrests. ${ }^{8}$ In essence, observance of the rule of law is of utmost importance, it enhances the strength of both the law and the state.

The influence of money on Nigerian politics is too pervasive and reform in this area should focus on the phenomenon of vote buying, which I have addressed elsewhere (Ojo 2006, pp 105-123). Free and fair elections may become a mirage unless this tendency is controlled. Former President Obasanjo averred:

With so much resources being deployed to capture elective offices, it is not difficult to see the correlation between politics and the potential for high level corruption. The greatest losers are the ordinary people, those voters whose faith and investment in the system are hijacked and subverted because money, not their will, is made the determining factor in elections. Can we not move from politics of money and materialism to politics of ideas issues and development?

Obasanjo \& Mabogunje 1992, p 138

In the same piece, he commented on the cost of conducting elections in Nigeria.

Even more worrisome, however, is the total absence of any control on spending by candidates and parties towards elections. I have said that we prepare for elections as if we are going to war, and I can state without hesitation, drawing from my previous life, that the parties and candidates together spent during the last elections more than would have been needed to fight a successful war.

Obasanjo \& Mabogunje 1992

In recognition of this problem the 2006 Electoral Act makes it an offence to sell or buy votes and places a ceiling on the amount a candidate may spend to fight an election (s 24(5) $\mathrm{a}_{1}, \mathrm{~b}_{4,}$ and c). Section 87(5) a and b with s 93(8) 1-11 deals extensively with the issue. The snag, however, is that of enforcement. ${ }^{9}$

8 One such 'godfather' is known to be a strongman in Ibadan politics in Oyo, in South-West Nigeria. For the form and character of the debilitating influence of 'godfatherism' in Nigerian politics, see Ayoade 2006, pp 78-87. See also Omatola, p 134 of this journal.

9 According to the 2006 Electoral Act (s 93 subss 1-7) a presidential candidate may not incur election expenses higher than $\$ 500000$ 000; a gubernatorial candidate $\$ 100000$ 000; a $\mathbb{N a t i o n a l ~ A s s e m b l y ~}$ candidate $\$ 20000$ 000; House of Representatives $\$ 10000$ 000; state assembly $\$ 5000$ 000; chairman N5 000 000; councillor N500 000. 


\section{CONCLUSION}

This paper has covered the crisis of political succession in post-colonial Nigeria. The problems with the conduct and administration of the 2007 general elections have been highlighted, showing what went wrong with the system. However, the reform dimensions are far from being exhaustive in the sense that the expected role of civil society organisations and the mass media, which I have dealt with elsewhere (Ojo 2003, pp 821-840), are excluded here because of space constraints.

No matter how profound reform dimensions may be in the Nigerian context, they may not achieve the desired goal unless politics is made less rewarding than it is now. For instance, the take-home pay of a local government councillor is outrageous, to say nothing of that of state representatives, members of the federal House of Representatives and senators. The high salaries and other remuneration which make politicians super-rich also make it difficult for them to let go if they lose at the polls. This is why electoral contests in Nigeria become a do-or-die affair.

Finally, politicians, too, need to be re-orientated. Currently there are politicians but no statesmen. If the citizenry is not sufficiently democratic democracy becomes a mirage. It is only when profound electoral reforms are carried out that Nigeria's recurring succession crisis will abate and democracy be sustained.

— REFERENCES

Adekanye, J. 2005. 'Reforming the Character of Civil-Military Relations for Democratic Governance in Nigeria after 1999'. Faculty of Social Sciences distinguished lecture series, No 8. University of Lagos, Nigeria, May.

Adesina, J O. 1998. 'Civil Society and Abacha State'. Quarterly Reviews, Lagos, January-March.

Adetula, V, I O Albert \& D Marco. 2007. 'Towards the 2007 Elections'. Ibadan: Stirling Horden Publishers.

Anise, L. 1974. 'Trends in Leadership Succession and Regime Change in African Politics since Independence'. African Studies Review 17(3).

Ayoade, John A A. 2006. Godfather Politics in Nigeria: Money, Politics and Corruption in Nigeria. Abuja: IFES-Nigeria, pp 78-87.

Becky, C et al. 1976. 'Political Succession in Eastern Europe'. Studies in Comparative Communism 9(1\&2), Spring/Summer.

Blondel, J. 1980. World Leaders. London and Beverly Hills: Sage Publications.

Dahl, R. 1971. Polyarchy: Participation and Opposition. New Haven: Yale University Press. 
Diamond L \& L Morlino. 2004. 'The Quality of Democracy: An Overview'. Journal of Democracy 15(4), October.

Ibeanu, O. 2007. 'Stimulating Landslides: Primitive Accumulation of Votes and the Popular Mandate in Nigeria'. In I O Albert, D Marco \& V Adetula (eds). Perspectives on the 2003 Elections in Nigeria. Ibadan: Stirling Horden Publishers Ltd.

International IDEA 2001. Democracy in Nigeria: Continuing Dialogue(s) for National Building. Sweden: Bulls Trycheri.

Londregan, J, H Bienen \& J van de Walle. 1995. 'Ethnicity and Leadership Succession in Africa'. International Studies Quarterly 39(1).

Obasanjo, O. November 2003. Address delivered at INEC-Civil Society Workshop on the Reform of the Legal Regime, held in Abuja with the participation of political parties.

Obodumu, K. 1992. ‘The Nigerian Military and Leadership Succession: A Materialist Examination of the Economic Foundation of Nigeria's Third Republic'. In B Caron, A Gboyega \& E E Osaghae (eds). Democratic Transition in Africa. Ibadan: CREDU, Institute of African Studies, University of Ibadan.

Ojo, E O. 2003a. 'Governance and Legitimacy Crisis in Nigeria'. Research for Development 18(1\&2).

— 2003b. 'The Mass Media and Challenges of Sustainable Democratic Values in Nigeria: Possibilities and Limitations'. Media, Culture and Society 25(6).

— . 2004. 'The Military and Political Transitions'. In A A B Agbeje, L Diamond \& E Onwudiwe (eds). Nigeria's Struggle for Democracy and Good Governance. Ibadan: Ibadan University Press.

— 2006a. 'Taming the Monster: Demilitarization and Democratization in Nigeria'. Armed Forces and Society 32(2), January.

— . 2006b. 'Vote-Buying in Nigeria'. Money, Politics and Corruption in Nigeria. Abuja: IFES-Nigeria.

Obasanjo, O \& A Mabogunje. 1992. Elements of Democracy. Abeokuta: ALF Publications.

Oyediran, O \& A A B Agbaje. 1999. 'Introduction'. In O Oyediran \& A A B Agbaje (eds). Nigeria: Politics of Transition and Governance 1986-1996. Dakar: CODESRIA. People. 2007. 'The Maurice Iwu Story: The Truth about 2007 Polls' . Abuja: Great and Gamaliel Alliance Ltd.

Pye, L W. 1976. 'Generational Politics in a Gerontocracy: The Chinese Succession Problem'. Current Scene 14(7).

Sandschneider, E. 1985. 'Political Succession in the People's Republic of China: Rule by Plunge'. Asian Survey 25(6).

Schumitter, P C. 2004. 'The Quality of Democracy: The Ambiguous Virtues of Accountability'. Journal of Democracy 15(4), October. 
Tell, Lagos. 2007. 'Controversial Polls: Why the System Failed', 7 May.

The Guardian, Lagos. 2007. 'Polls Fall Short of International Standards: Fail to Meet Expectations of Nigerians, says EU Team', 24 April.

The Nation, Lagos. 2007. 'No Succumbing to Sham Elections', 19 April.

— .26 August 2007. 'Election Petition Tribunals: How Far?'

The News 29(08). 2007. 'Akala: The Road to the End', 3 September. 